https://doi.org/10.30910/turkjans.595202



TÜRK

DERGISI

\section{Araştırma Makalesi}

\title{
Tescilli Fasulye Çeşitlerinin Pas (Uromyces appendiculatus) Etmenine Karşı Dayanıklılık Durumlarının SCAR Markörleri ile Belirlenmesi
}

TURKISH

JOURNAL Of AGRICULTURAL and NATURAL SCIENCES

www.dergipark.gov.tr/turkjans

\author{
Mehmet Zahit YEKEN ${ }^{1}$, Göksel ÖZER ${ }^{2}$, Ali ÇELiK²*, Vahdettin ÇifTÇi'
}

${ }^{1}$ Bolu Abant İzzet Baysal Üniversitesi Ziraat ve Doğa Bilimleri Fakültesi Tarla Bitkileri Bölümü, BOLU

${ }^{2}$ Bolu Abant İzzet Baysal Üniversitesi Ziraat ve Doğa Bilimleri Fakültesi Bitki Koruma Bölümü, BOLU

*Sorumlu yazar: alicelik@ibu.edu.tr

Geliş Tarihi: 19.02.2019

Düzeltme Geliş Tarihi: 31.05.2019

Kabul Tarihi: 26.06.2019

Özet

Fasulye pas hastalığı tüm dünyada fasulye üretiminde sorun oluşturan önemli fungal hastalıklardan birisidir. Fasulye pası ile en etkili ve çevre açısından en zararsız mücadele şekli dayanıklı çeşit ıslahı ve kullanımıdır. Son yıllarda geliştirilen moleküler markörler sayesinde hastalıklara karşı dayanıklıık önceden belirlenebilmekte ve ıslah programları bu veriler ışığında planlanabilmektedir. Bu çalışmada, Türkiye'de yaygın olarak yetiştiriciliği yapılan 43 tescilli fasulye çeşidinin pas hastalığına dayanıklıık durumları SCAR markörleri ile incelenmiştir. Dayanıklılıkla ilgili 4 farklı markör (SA14, SI19, SBC6, AE19) yardımıyla yapılan PCR çalışmaları bazı çeşitlerin pas hastalığına karşı dayanıkılık sağlayan genlere sahip olduklarını ortaya çıkarmıştır. Elde edilen tarama sonuçlarının mevcut çeşitlerin dayanıkılık durumlarını ortaya koymasının yanı sıra, pas ile ilgili yapılacak moleküler destekli dayanıkılık ıslahı çalışmalarının temelini oluşturacağı ön görülmektedir.

Anahtar kelimeler: Pas, Uromyces appendiculatus, dayanıklılık, markör destekli seleksiyon.

\section{Determination of the Resistance to the Bean Rust (Uromyces appendiculatus) in Registered Bean Varieties by Using SCAR Markers}

\begin{abstract}
Bean rust disease is one of the most important fungal diseases of limiting the yields of common bean all over the world. The most effective and the most harmless methods against the bean rust pathogen are breeding and use of the resistant varieties. Resistance to diseases can be previously determined in breeding programs with the critical data obtained from molecular markers developed in recent years. In this study, resistance against bean rust was investigated by SCAR markers in 43 registered bean varieties, which is widely cultivated in Turkey. As a result, PCR studies performed with 4 different markers (SA14, SI19, SBC6, AE19) which characterize the genes related to resistance revealed that some varieties have the genes linked to the resistance. In addition to revealing the current status of the registered varieties, the results of the study are expected to support new breeding programs.
\end{abstract}

Key words: Bean rust, Uromyces appendiculatus, resistance, marker-assisted selection.

\section{Giriş}

Uromyces appendiculatus (Pers.) Unger. fungusunun neden olduğu pas hastalığı fasulye üretimini sınırlandıran en önemli fungal hastalıklar arasında yer almaktadır. Uygun konukçunun varlığı ve şartların patojen lehine seyrettiği dönemlerde hastalık önemli kayıplara yol açan epidemilere neden olabilmektedir. $U$. appendiculatus, pasların beş dönemi içeren ve ara konukçusu olmayan bir hayat döngüsüne sahip iken bitki üzerinde genellikle hastalık 
etmeninin üredosporlar ve teliosporları göze çarpmaktadır. Pas etmeni üretim alanında bitki artıkları üzerinde istirahat aşaması (kışlama) görevi görmekte olan teliosporlar ile kışı geçirmektedir (Beije ve ark. 1984). Ancak, etmen kışın sert olmadığı bölgelerde üredospor olarak da yaşam çemberini tamamlayabilmektedir. Çok düşük düzeyde böceklerle veya insan faktörü ile yayılabilmekle birlikte, enfeksiyon bitkiden bitkiye çoğunlukla üredosporlar tarafından yayılmaktadır. Etmenin uzun mesafelere taşınması büyük ölçüde rüzgarla dağılan üredopsorlardan kaynaklanmaktadır. Üredosporlar, yüksek bağıl nem ve yaprak yüzeyinde bulunan en az 6-8 saat ıslaklık koşullarında $17{ }^{\circ} \mathrm{C}$ ve $23^{\circ} \mathrm{C}$ arasındaki sıcaklıklarda çimlenmekte olup, hastalık oluşumu gecelerin nemli, günlerin kuru ve ılık olduğu bölgelerde maksimuma ulaşmaktadır (Imhoff ve ark. 1982; Boudreau ve Mundt 1992). Hastalığın gelişimi, inokulum konsantrasyonunun yanı sıra fotosentetik aktivite ve topraktaki bitki besin elementlerinin varlığı gibi konukçu faktörleri ile yakından ilgilidir (Agrios 1997).

Hastalığın dünyanın çeşitli bölgelerinde (Çin, USA, Avrupa, Etiyopya, Kenya, Güney Afrika, Tanzanya) epidemi yaptığı rapor edilmiştir (Souza ve ark. 2008). Brezilya'nın güneyinde sıklıkla epidemi yapmakta ve bölgede ciddi verim kayıplarına yol açabilmektedir (Souza ve ark. 2005). Ülkemizde kuru ve taze fasulye çeşitlerinde \%18-100'e varan oranlarda verim kaybına neden olduğu bildirilmiştir (Altıkardeşler ve Arslan 2007).

Fasulye pası ile en etkili ve çevre açısından en zararsız mücadele şekli dayanıklı çeşit ıslahı ve kullanımıdır. Özellikle epidemi tehlikesi yüksek olan bazı coğrafyalarda dayanıklı çeşit kullanımının önemi daha da ön plana çıkmaktadır (Mmbaga ve ark. 1996). Bununla birlikte, pas etmeninin yüksek patojenik ve genetik çeşitliliği, mutlak dayanıklı ve tolerant çeşitlerin ıslahını zorlaştırmaktadır. Bu zorluk, bir yılda birden fazla fasulye yetiştirme periyodunun yaşandığı tropik bölgelerde uygun sıcaklık ve yeterli nemin de etkisiyle artış gösterebilmektedir (Acevedo ve ark. 2013). Fasulye genomunda, pas etmeninin farklı patotiplerine karşı dayanıklılıkla ilgili birçok gen tanımlanmıştır. Bu genler arasında Ur-3, Ur-4, Ur-5, Ur-6, Ur-7, Ur-9 / Ur-12, Ur-11, Ur-13, Ur-Ouro Negro ve Ur-Resisto yer almaktadır (Liebenberg ve ark. 2006). Bazı fasulye çeşitlerinde dayanıklılıkla ilgili farklı lokusların da varlığı anlaşılmakla birlikte tam olarak karakterize edilememiştir (Liebenberg ve ark. 2006). Fasulye pas etmeninin patotiplerine veya fizyolojik ırklara karşı birçok dayanıklılık kaynağı mevcut olmakla birlikte, bu kaynakların hiçbiri tüm ırklara karşı dayanıklılık sağlamadığı çeşitli araştırıcılar tarafından bildirilmiştir (Stavely ve ark. 1994a; Stavely ve ark. 1994b; Stedman ve ark. 2002; Paster Corrales 2003; Park ve ark. 2004).

Altıkardeşler ve Arslan (2007), Bursa ilinden 2004 yılında topladıkları pas izolatlarını kontrollü koşullarda bazı fasulye çeşitlerine inokule ederek, çeşitlerin reaksiyonlarını simptomatolojik olarak kaydetmişler ve çeşitleri bağışık, yüksek ve orta derece dayanıklı ve duyarlı olarak sınıflandırıp, sadece Alman Ayşe çeşidinin dayanıklı diğer çeşitlerin duyarlı olduğu belirlemişlerdir. Markör destekli seleksiyon yardımı ile dayanıkılık genlerinin tespiti çalışmaları patojen inokulasyonuna gerek kalmaksızın bitkilerde söz konusu genlerin varlığının belirlenebilmesine imkân sağladığı için günümüzde yoğun olarak kullanım alanı bulan bir yöntemdir. Bu çalışmada Türkiye'de yaygın olarak yetiştiriciliği yapılan 43 tescilli fasulye çeşidinin pas hastalığına dayanıklılık durumları "sekansı karakterize edilmiş çoğaltılmış bölgeler" (Sequence Characterized Amplified Regions = SCAR) markörleri ile incelenmiştir. Elde edilen sonuçların ileride fasulyede yapılacak olan dayanıklılık ıslahı çalışmalarına destek olacağı düşünülmektedir.

\section{Materyal ve Yöntem}

Araştırmada 43 tescilli fasulye çeşidi ile Amerika Birleşik Devletleri Tarım Bakanlığı (USDA)'dan temin edilen 4 referans fasulye genotipi materyal olarak kullanılmıştır (Çizelge 1). Tüm fasulye genotipleri $23^{\circ} \mathrm{C}$ sıcaklık ve $14 / 10$ saatlik ışık periyodu içeren kontrollü bitki yetiştirme odalarında yetiştirilmiştir. Bu amaçla \%1'lik $\mathrm{NaClO}$ solüsyonunda 1 dakika süreyle yüzeysel dezenfeksiyona tabi tutulan tohumlar toprak, kum, gübre karışımı içeren (1:1:1 v/v) $16 \mathrm{~cm}$ çapındaki saksılara ekilmiştir. DNA izolasyonu için 10 günlük fidelerden alınan yaprak dokuları kullanılmış olup, izolasyon GeneJET Plant Genomic DNA Purification Kit (Thermo Scientific, USA) kullanılarak gerçekleştirilmiştir. Elde edilen DNA'lar bir DS-11 spektrofotometre (Denovix, USA) yardımıyla $10 \mathrm{ng} / \mu \mathrm{L}$ konsantrasyonda ayarlanarak $-20{ }^{\circ} \mathrm{C}$ ' de saklanmıştır. Her bir fasulye genotipi fasulye pası ile ilişkili olduğu bildirilen genlerle ilişkili moleküler markörler kullanılarak taranmıştır (Çizelge 2).

PCR amplifikasyonları $0.2 \mathrm{mM}$ dNTPs, $0.3 \mu \mathrm{M}$ primer, $1.5 \mathrm{mM} \mathrm{MgCl}$, 1 x PCR buffer, 10-20 ng DNA, 1 U Taq DNA polimeraz (EP0402: Thermo Scientific, USA) içeren $25 \mu l^{\prime}$ lik hacimlerde bir T100 thermal cycler (Bio-Rad, USA) içerisinde gerçekleştirilmiştir. Amplifikasyon koşulları ilgili literatürlerde belirtilenlere uygun olarak gerçekleştirilmiştir (Çizelge 2). Elde edilen PCR ürünleri \%1.4'lük agaroz jelde 100 
V'da 90 dk süreyle koşturulmuş ve bir G: Box F3 Jel görüntüleme sisteminde (Syngene, UK) görüntülenmiştir. Beklenilen $\quad P C R$ ürünlerinin büyüklükleri 100 bp DNA ladder kullanılarak tespit edilmiştir.

Araştırmada, genotiplerin SA14 ve SI19 markörlerinden elde edilen jel görüntüleri " $0=$ Yok
1=Var" şeklinde skorlanmıştır. Elde edilen tüm değerler JMP 14.1.0 istatistik programında (SAS Institute Inc., Cary, NC, USA) kümeleme (Cluster) analizine tabi tutulmuş ve renk haritası oluşturulmuştur.

Çizelge 1. Çalışmada kullanılan tescilli fasulye çeşitleri

\begin{tabular}{clcclcclc}
\hline No & Çeşit adı & Tipi* & No & Çeşit adı & Tipi & No & Çeşit adı & Tipiı \\
\hline 1 & Zülbiye & KF & 16 & Batallı & KF & 31 & Cihan & KF \\
2 & Remi & TF & 17 & Göksun & KF & 32 & Bulduk & KF \\
3 & Özdemir & KF & 18 & Mecidiye & KF & 33 & 40 Günlük & TF \\
4 & Kantar-05 & KF & 19 & 4F-89 Fransız & TF & 34 & Bourgondia & TF \\
5 & Sazova 1949 & TF & 20 & Bona & TF & 35 & Karabacak & TF \\
6 & Gina & TF & 21 & Romano 26 & TF & 36 & Akın & KF \\
7 & Karacaşehir 90 & KF & 22 & Klas & TF & 37 & Akman 98 \\
8 & Alman Ayşe-4 & TF & 23 & Göynük 98 & KF & 38 & Terzibaba \\
9 & Zirve & KF & 24 & Güngör & KF & 39 & Önceler 98 \\
10 & Işıkı & TF & 25 & Elkoca-05 & KF & 40 & Berrak \\
11 & Askız & TF & 26 & Sembol & TF & 41 & Yakutiye 98 \\
12 & Mina & TF & 27 & Aras 98 & KF & 42 & Akdağ & KF \\
13 & Sarıkız & TF & 28 & Nina & TF & 43 & Arslan & KF \\
14 & Helda & TF & 29 & Sururbey & KF & & KF \\
15 & Albeni & TF & 30 & Sülün & TF & & \\
\hline
\end{tabular}

${ }^{*}$ KF Kuru Fasulye, TF Taze Fasulye.

Çizelge 2. Çalışmada kullanılan SCAR markörleri

\begin{tabular}{|c|c|c|c|}
\hline $\begin{array}{l}\text { Primer } \\
\text { adı }\end{array}$ & $\begin{array}{l}\text { Gen } \\
\text { bölgesi }\end{array}$ & PCR Koşulları & Referans \\
\hline SA14 & $U r-4$ & $\begin{array}{l}94{ }^{\circ} \mathrm{C} 5 \mathrm{dk} ; 94{ }^{\circ} \mathrm{C} 60 \mathrm{sn}, 55^{\circ} \mathrm{C} 60 \mathrm{sn}, 72{ }^{\circ} \mathrm{C} 90 \\
\text { sn } 35 \text { döngü ve } 72{ }^{\circ} \mathrm{C} 5 \mathrm{dk}\end{array}$ & Miklas ve ark., 2002, Meine ve ark. 2004. \\
\hline SI19 & $U r-5$ & $\begin{array}{l}94{ }^{\circ} \mathrm{C} \text { de } 3 \mathrm{dk}, 94{ }^{\circ} \mathrm{C} 1 \mathrm{dk}, 50{ }^{\circ} \mathrm{C} 1.5 \mathrm{dk}, 72{ }^{\circ} \mathrm{C} \\
1.5 \mathrm{dk}, 35 \mathrm{döngü} 72 \mathrm{C} 7 \mathrm{dk}\end{array}$ & Souza ve ark. 2007. \\
\hline SBC6 & Ur-6 & $\begin{array}{l}95{ }^{\circ} \mathrm{C} 2 \mathrm{dk} ; 94{ }^{\circ} \mathrm{C} 30 \mathrm{sn}, 59{ }^{\circ} \mathrm{C} 60 \mathrm{sn}, 72{ }^{\circ} \mathrm{C} 2 \\
\mathrm{dk} 30 \text { döngü ve } 72{ }^{\circ} \mathrm{C} 5 \mathrm{dk}\end{array}$ & Miklas ve ark. 2002, Park ve ark. 2004. \\
\hline AE19 & $U r-11$ & $\begin{array}{l}94{ }^{\circ} \mathrm{C} 5 \mathrm{dk} ; 94{ }^{\circ} \mathrm{C} 15 \mathrm{sn}, 58{ }^{\circ} \mathrm{C} 60 \mathrm{sn}, 72{ }^{\circ} \mathrm{C} 90 \\
\text { sn } 35 \text { döngü ve } 72{ }^{\circ} \mathrm{C} 5 \mathrm{dk}\end{array}$ & $\begin{array}{l}\text { Miklas ve ark. 2002, Alzate-Marin ve ark. } \\
\text { 2003, Queiroz ve ark. } 2004 .\end{array}$ \\
\hline
\end{tabular}

Çizelge 3. Çalışmada kullanılan USDA'dan elde edilen ayırıcı set genotipleri

\begin{tabular}{cc}
\hline Genotip & Gen Havuzu* \\
\hline Perry Marrow & $A$ \\
Cornell 49242 & $M A$ \\
TO & $M A$ \\
Ouro Negro & $M A$ \\
\hline
\end{tabular}

${ }^{*} \mathrm{MA}=$ Orta Amerikan gen havuzu; $\mathrm{A}=$ Andean gen havuzu.

\section{Bulgular ve Tartışma}

Uromyces appendiculatus'un neden olduğu pas hastalığına karşı fasulye genotiplerinde dayanıklılık sağlayan genlerin moleküler markörler yardımıyla belirlenebilmesi için yapılan çalışmada 43 fasulye çeşidi ve 4 yurt dışı kaynaklı genotipten DNA izolasyonu gerçekleştirilmiş ve bu bitkilerde dayanıklılık genlerin varlığı 4 farklı SCAR markörü ile incelenmiştir. Yapılan PCR çalışmaları sonucunda SBC6 ve $A E 19$ primerlerinden herhangi amplifike ürün elde edilememiş iken SA14 (1079/800 bp) ve SI19 (460 bp) 
primerlerinden elde edilen jel görüntüleri skorlanmıştır (1:Var, 0:Yok). Skorlama sonucunda elde edilen değerler kümeleme analizine tabi tutulmuş ve renk haritası belirlenmiştir. Renk haritasında dayanıkılık geni içeren genotipler kırmızı, içermeyenler mavi renk ile kodlanmıştır (Şekil 2). Yapılan kümeleme analizi sonucunda genotiplerin dayanıklılık genleri bakımından iki ana gruba (Grup A ve Grup B) ayrıldığı görülmektedir. A grubu içerisindeki 27 çeşit ile Perry Marrow ve TO genotiplerinin $U r-4$ genlerini taşıdığı ve bu gruptaki genotiplerin $U r-5$ genine ise sahip olmadığı belirlenmiştir. Çalışma, beklenen bant büyüklüğü yönüyle Miene ve ark. (2004) ile benzer sonuçlar göstermiştir. Miene ve ark. (2004) 'e göre 1079 bp çiftinde bant profiline sahip genotiplerin Ur-4 genini bünyelerinde bulundurduğu değerlendirilirken yaklaşık 800 bp amplifkasyon elde edilen genotiplerin Ur-4 geninden yoksun olduğu kabul edilmiştir (Şekil 1). Altıkardeşler ve Arslan (2007) tarafından dayanıklı olarak rapor edilmiş olan Alman Ayşe çeşidi, gerçekleştirilen bu çalışmada Ur-4 genini içermediğinden dolayı hastalığa hassas olarak karakterize edilmiştir. Bu durum markör destekli seleksiyon çalışmalarında kullanılan SCAR markörlerinin dayanıklılıkla ilgili lokuslara belirli oranda bağlantılı olması ile açıklanabilir.



Şekil 1. SA14 (1079/800 bp) markörü ile elde edilen jel görüntüsü (Şekil 1A,1B), SI19 (460 bp) markörü ile elde edilen jel görüntüsü (Şekil 1C).

Markörler yardımıyla yapılan genotipik karakterizasyonlar, çeşitlerin hastalığa dayanıklılık derecelerinin klasik patojenisite çalışmaları ile kuvvetlendirilecektir (Miklas 2002). Grup B incelendiğinde kendi içerisinde B1 ve B2 olarak iki alt gruba ayrıldığı görülmektedir (Şekil 2). B1 alt grubu kendi içerisinde B1.1 ve B1.2 olarak iki alt grubu ayrıldığı ve renk haritasında da görüldüğü üzere B1.1'de yer alan Özdemir ve Sarıkız çeşitlerinin Ur-4 ve Ur-5 dayanıklılık genlerini içerdiği belirlenmiştir. B1.2 
alt grubunun içerisinde yer alan Kantar-05, Göksun, Akman-98, Berrak, Aslan ve Cornell 49242'nin ise sadece Ur-5 genini bulundurmasından dolayı aynı grupta kümelendiği saptanmıştır. Kümeleme analizi sonucunda Karacaşehir-90, Alman Ayşe, Zirve, Helda, Batallı, Mecidiye, Güngör, Bourgoundia, Terzibaba ve Ouro Negro genotiplerinin Ur-4 ve Ur-5 dayanıklılık genlerine sahip olmadığı saptanmıştır. Çalışmada kullanılan SI19 markörü Ur-5 lokusu için elde edilen amplikon büyüklüğü yönüyle Souza ve ark. (2007) ile benzer sonuçlar sergilemiştir. Miklas (2002), Ur-4 ve Ur-5 genlerinin Ur-11 içerisinde yer alan bir lokus üzerinde konumlandığını bildirmiştir (Miklas 2002). Dayanıklılıkla ilgili olduğu bilinen Ur-11 geninin karakterizasyonu üzerinde çeşitli çalışmalar yapılmıştır (Beaver ve Macchiavelli 2002; Pastor Corrales 2002; Pastor-Corrales ve Stavely 2002).
Yapılan moleküler tarama sonucunda Ur-4 + Ur-5 geninin varlığı sadece Sarıkız ve Özdemir çeşitlerinde tespit edilmiştir. Söz konusu iki genin varlığı bakımından Sarıkız ve Özdemir çeşitlerinin pas hastalığına diğer çeşitlere nazaran daha dayanıklı olması beklenmekte ise de bu durumun patojenisite çalışmaları ile doğrulanması ve fenotipik olarak da karakterize edilmesi gerekmektedir. Ayrıca Ur-5 geni içeren ancak Ur-4 geninden yoksun olan Kantar-05, Göksun, Akman 98, Berrak ve Arslan çeşitlerinin de hastalığa karşı reaksiyonlarının değerlendirilmesi bu genlerin fonksiyonlarının anlaşılması bakımından önemlidir. Kümeleme analizi ile elde edilen sonuçlar, genotiplerin dayanıklılık genlerini içermeleri yönünden anlamlı bir şekilde gruplandığını, dolayısıyla ileride yapılacak ıslah çalışmalarında bu gruplardan başarıyla faydalanılabileceğini göstermektedir.

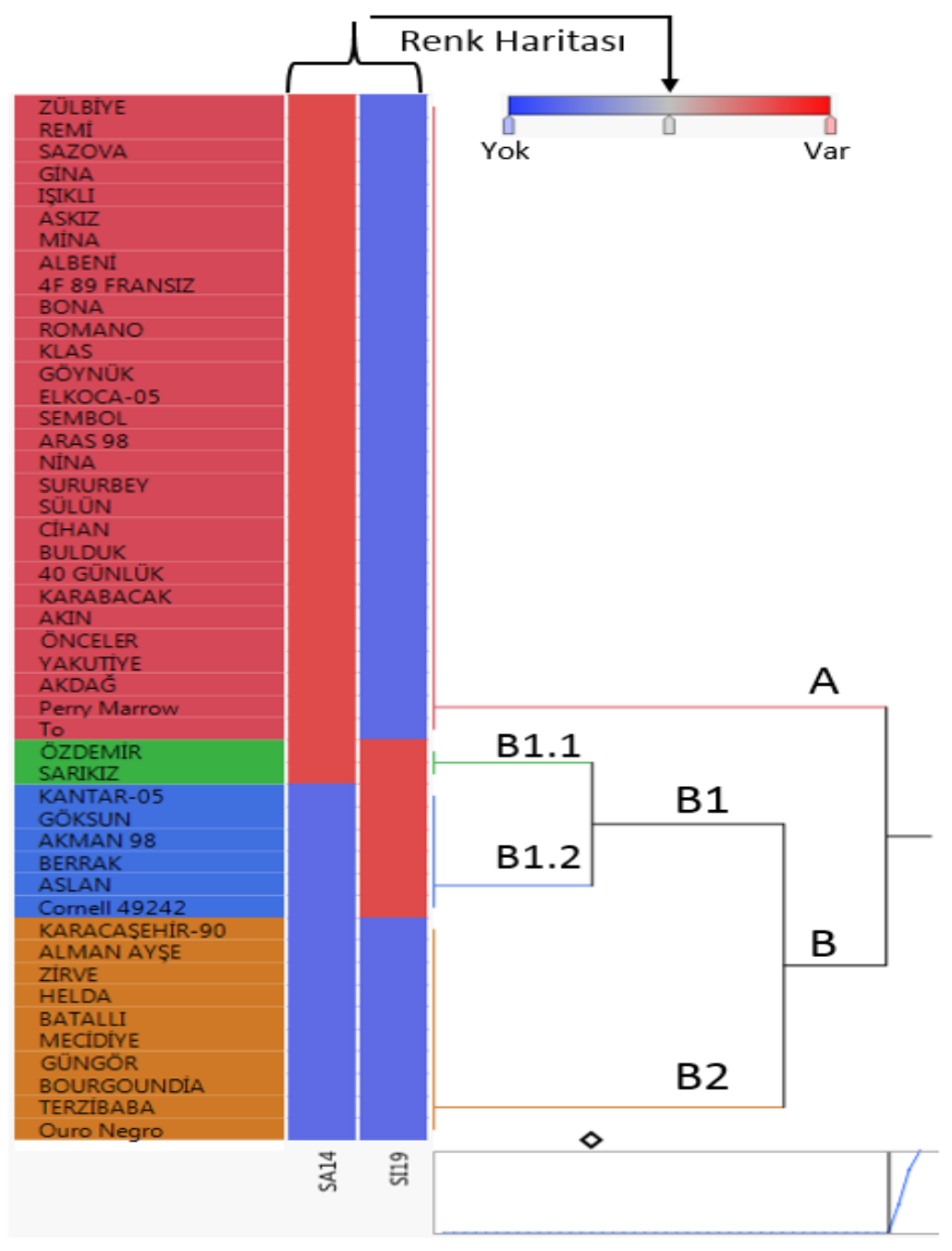

Şekil 2. Genotiplerin SA14 ve SI19 markörlerine göre kümeleme analizi ve renk haritası. 


\section{Sonuç ve Öneriler}

SCAR markörleri ile yapılan tarama neticesinde 43 tescilli çeşit arasından önemli bir kısmının pas hastalığına dayanıklılık ile ilişkili olan Ur-4 ve Ur-5 genlerine sahip oldukları belirlenmiştir. Fasulye pası hastalığının ülkemizde uygun koşullar altında epidemi yaptığı bilinmektedir. Dünyada olduğu gibi ülkemizde de hastalıkla mücadelede dayanıklı veya tolerant çeşitlerin kullanımı önerilmektedir. Çalışma sonucunda Sarıkız ve Özdemir çeşidinin dayanıklılıkla ilişkili her iki geni de bünyesinde bulundurması sebebiyle hastalığa dayanıklı olması ön görülmektedir. Sonuç olarak, markörler kullanılarak dayanıklılık genlerinin varlığı noktasında karakterize edilen çeşitlerin klasik patojenisite sonucu elde edilecek fenotipik gözlemler ile dayanıklılık durumlarının doğrulanması önerilmektedir.

\section{Teşekkür}

Bu çalışma Bolu Abant İzzet Baysal Üniversitesi Bilimsel Araştırma Projeleri birimi tarafından BAP 2016.10.07.1091 no'lu proje kapsamında desteklenmiştir.

\section{Kaynaklar}

Acevedo, M., Steadman, J.R., Rosas, J.C. 2013. Uromyces appendiculatus in Honduras: pathogen diversity and host resistance screening. Plant disease, 97(5): 652-661.

Agrios G.N. 1997. Plant Pathology, 4th ed. Academic Press, Inc, San Diego, California, pp. 633.

Altıkardeşler, A., Arslan, Ü. 2007. Fasulye (Phaseolus vulgaris L.) Çeşitlerinin Pas Hastalığı (Uromyces appendiculatus (Pers.: Pers.) Unger)'na Karşı Reaksiyonları ve Bazı Fungisitlerin Etkisi. Journal of Agricultural Faculty, 21(1): 18.

Alzate-Marin, A.L., Costa M.R., Arruda, K.M., Barros, E.G., Moreira, M.A. 2003. Characterization of the anthracnose resistance gene present in Ouro Negro (Honduras 35) common bean cultivar. Euphytica, 133: 165-169.

Beaver, J.S., Macchiavelli, R. 2002. Utility of the multiple-seed procedure of single-seed descent for bean improvement. Annual Report-Bean Improvement Cooperative, 45: 34-35.

Beije, C.M., Kanyagia, S.T., Muriuki, S.J.N., Otieno, E.A., Self, A.A., Whittle, A.M. 1984. Horticultural Protection Handbook. National Horticulture Research Station, Ministry of Agriculture and Livestock Development, Thika, Kenya, pp. 32.
Boudreau, M.A., Mundt, C.C. 1992. Mechanisms of alteration in bean rust epidemiology due to intercropping with maize. Phytopathology, 82: 1051-1060.

Imhoff, M.W., Leonard, K.J., Main, C.E. 1982. Analysis of disease progress curves, gradients and incidence-severity relationships for field and phytotron bean rust epidemics. Phytopathology, 72: 72-80.

Liebenberg, M.M., Mienie, C.M.S., Pretorious, Z.A. 2006. The Occurrence of rust resistance gene Ur-13 in common bean cultivars and lines. Euphytica, 150: 365-386.

Meine, C.M.S., Naidoo, R., Liebenberg, M.M. 2004. Conversion of the RAPD marker for Ur-4 to a co-dominant SCAR marker SA141079/800. Annual Report-Bean Improvement Cooperative, 47: 261-262.

Miklas, P.N. 2002. Marker-assisted selection for disease resistance in common bean. Annual Report-Bean Improvement Cooperatıve, 45: 13.

Miklas, P.N., Pastor-Corrales, M.A., Jung, G., Coyne, D.P., Kelly J.D., McClean P.E., Gepts, P. 2002. Comprehensive linkage map of bean rust resistance genes. Annual Report-Bean Improvement Cooperatıve, 45: 125-129.

Mmbaga, M.T., Steadman, J.R., Stavely, J.R. 1996. The use of host resistance in disease management of rust in common bean. Integrated Pest Management Reviews, 1: 191-200.

Park, S.O., Coyne, D.P., Steadman, J.R., Crosby, K.M., Brick, M.A. 2004. RAPD and SCAR markers linked to the Ur-6 Andean gene controlling specific rust resistance in common bean. Crop Science, 44: 1799-1807.

Pastor-Corrales, M.A. 2002. Apparent vulnerability of certain of rust-resistance gene combinations in common bean for the management of Uromyces appendiculatus. Annual ReportBean Improvement Cooperative, 45: 42-43.

Pastor-Corrales, M.A. 2003. Sources, genes for resistance and pedigrees of 52 rust and mosaic resistant dry bean germplasm lines released by the USDA Beltsville bean project in collaboration with Michigan, Nebraska and North Dakota agricultural experiment stations. Annual Report-Bean Improvement Cooperative, 46: 235-241.

Pastor-Corrales, M.A., Stavely, J.R. 2002. Using specific races of the common bean rust pathogen to detect resistance genes in 
Phaseolus vulgaris. Annual Report-Bean Improvement Cooperative, 45: 78-79.

Queiroz, V.T., Sousa, C.S., Costa, M.R., Sanglad, D.A., Arruda, K.M.A., Souza, T.L.P.O., Ragagnin, V.A., Barros, E.G., Moreira, M.A. 2004. Development of SCAR markers linked to common bean anthracnose resistance genes Co-4 and Co-6. Annual Report-Bean Improvement Cooperative, 47: 249-250.

Souza, T.L.P.O., Alzate-Marin, A.L., Moreira, M.A., Barros, E.G.D. 2005. Análise comparativa da variabilidade patogênica de Uromyces appendiculatus em algumas regiões brasileiras. Fitopatologia Brasileira, 30: 143149.

Souza, T.L.P.O., Alzate-Marin, A.L., Dessaune, S.N., Nunes, E.S., de Queiroz, V.T., Moreira, M.A., de Barros, E.G. 2007. Inheritance study and validation of SCAR molecular marker for rust resistance in common bean. Crop Breeding and Applied Technology, 7(1): 11-15.

Souza, T.L.P.O., Alzate-Marin, A.L., Faleiro, F.G., Barros, E.G. 2008. Pathosystem common beanUromyces appendiculatus: host resistance, pathogen specialization, and breeding for rust resistance. Pest Technology, 2(2): 56-69.

Stavely, J.R., Kelly, J.D., Grafton, K.F. 1994a. BelMiDakrustresistant navy dry bean germplasm lines. HortScience 29: 709-711.

Stavely, J.R., Kelly, J.D., Grafton, K.F., Steinke, J., Steadman J.R., Coyne, D.P., Lindgren, D.T., Silbernagel, M.J. 1994b. Recent rust resistant bean germplasm releases. Annual Report-Bean Improvement Cooperatıve, 37: 247- 248.

Steadman, J.R., Pastor-Corrales, M.A., Beaver, J.S. 2002. An overview of the 3rd bean rust and 2nd bean common bacterial blight international workshops. Annual Report-Bean Improvement Cooperatıve, 45: 120-124. 